\title{
Effect of social screening on funds' performance: empirical evidence of European equity funds
}

\section{Efecto del cribado social sobre la eficiencia de los fondos: evidencia empírica de los fondos de renta variable europeos}

\author{
José L. Fernández Sánchez* and Ladislao Luna Sotorrío \\ Departamento de Administración de Empresas, Universidad de Cantabria, Santander, Spain
}

(Received 1 December 2010; accepted 12 November 2013)

\begin{abstract}
The aim of this study is to evaluate the financial performance of European socially responsible investment (SRI) funds for the period 1993-2012 to contrast whether there is a relationship between the application of social screening on investment decisions and funds' financial performance measured by Carhart's alpha. Regression analysis has been used to test the hypotheses of this research with a sample free of survivorship bias of 184 SRI equity funds from 14 European countries and the population of conventional funds from the same country and investment objective. The main conclusion of this study is that the application of social criteria in investment decisions carries a cost to the investor in terms of lower financial performance caused by differences in screening intensity.
\end{abstract}

Keywords: SRI; ethical fund; social screening; social responsibility; performance; portfolio theory

El objetivo de este trabajo es evaluar la eficiencia financiera de los fondos socialmente responsables europeos durante el periodo 1993-2012 a fin de contrastar si existe una relación entre la aplicación del cribado social en las decisiones de inversión y la eficiencia financiera del fondo medida con el alfa de Carhart. El análisis de regresión ha sido empleado para contrastar las hipótesis de esta investigación con una muestra libre de sesgo de supervivencia de 184 fondos sociales de renta variable de 14 países europeos y la población de fondos convencionales del mismo país y objetivo de inversión. La principal conclusión de este estudio es que la aplicación de criterios sociales en las decisiones de inversión conlleva un coste para el inversor en términos de una menor eficiencia financiera causada por diferencias en la intensidad del cribado social.

Palabras clave: ISR; fondo ético; cribado social; responsabilidad social; eficiencia; teoría de cartera

\section{Introduction}

Numerous empirical studies have been published in recent years testing whether financial performance of the so-called socially responsible investment (SRI) funds is significantly better or worse than that of conventional funds. The main aim of all these studies is to test whether the use of ethical or social criteria in investment decisions really involves the

*Corresponding author. Email: fernandezj1@unican.es 
acceptance on the part of the investor of a lower return, which will demonstrate a change in the economic rationale of agents.

The discussion of whether levels of return are lower or risk higher for SRI funds is usually supported by two different theories:

- According to the modern portfolio theory, reducing the range of possible investments by including ethical or social considerations in the investment policy of the portfolio, what is called social screening, increases total portfolio risk, transaction costs and management fees reducing funds' performance (Hickman, Teets, \& Kohls, 1999; Rudd, 1981; Tippet, 2001).

- For the classical theory of the firm, the firm's need to supply information to SRI funds and to adapt its management to the social requirements of these funds involves some costs (agency and opportunity costs) that have no economic aim and so there must be an adverse effect on the profitability of the firm (Belkaoui \& Karpik, 1989). Thus, the lower profitability of socially responsible firms will affect negatively the returns of SRI funds.

On the other hand, the reasons given by the social theory to explain how SRI funds might achieve financial performance as good as or better than that of conventional funds, despite constraining their range of possible investments by applying ethical or social considerations in addition to purely economic ones, are the following:

- Firms acting in accordance with certain ethical criteria are more efficient and better managed, leading to their outperformance in the market (Goldreyer \& Diltz, 1999; Guerard, 1997; Hamilton, Jo, \& Statman, 1993; Tippet, 2001).

- SRI fund managers need more knowledge about the firms they invest in than do those of conventional funds and so base their decisions on more detailed, fuller and higher quality information, thus reducing the risk of their decisions (Goldreyer \& Diltz, 1999; Kurtz, 1997).

- SRI funds invest in smaller firms, which adapt more easily to changing market conditions (Gregory, Matatko, \& Luther, 1997; Luther, Matatko, \& Corner, 1992).

The empirical evidence obtained in studies carried out to date has failed to support any of the arguments or theories described above (Bauer, Koedijk, \& Otten, 2005; FernandezIzquierdo \& Matallin-Saez, 2008; Fernández Sánchez \& Luna Sotorrío, 2006; Goldreyer \& Diltz, 1999; Gregory et al., 1997; Gregory \& Whittaker, 2007; Hamilton et al., 1993; Kreander, Gray, Power, \& Sinclair, 2005; Mallin, Saadouni, \& Briston, 1995; Matallín Sáez \& Fernández Izquierdo, 2002; Scholtens, 2005; Statman, 2000) so that researches must ask themselves why the obtained results are not in agreement with the theoretical propositions. Consequently, more research is necessary to explain why relationship between the application of social criteria on investment decisions and financial performance is not found.

Thus, the aim of this study is to evaluate the financial performance of European equity funds to contrast whether there is a significant difference in performance between social and conventional funds analysing, specially, the effect of social screening on funds' performance. In response to this objective, the following null hypothesis is put forward:

$\mathrm{H}_{1}$ : The financial performance of SRI and conventional funds is the same. 
The absence of conclusive results in former studies may be due to there being important differences among the SRI funds themselves. One of these differences is the investment policy applied by SRI fund managers (ethical or social criteria used to select the assets making up funds' portfolio), which may affect the financial performance of these funds. For SRI funds that apply exclusion criteria (negative screening), it would be logical to expect their investment portfolio to be more constrained. Therefore, according to the modern portfolio theory, this type of fund would be subject to greater total risk than the rest. Moreover, the return of these funds may be lower since they cannot invest in certain profitable sectors or industries (Boasson, Cheng, \& Boasson, 2004; Tippet, 2001).

On the other hand, SRI funds that apply inclusion criteria (positive screening) would invest theoretically in the best managed firms of each sector and so, in accordance with the social theory of the firm, the financial performance of this type of fund would be higher than that of the rest (Guerard, 1997; Tippet, 2001). Similarly, since the firms in which these funds invest manage their economic, social and environmental risks better, the risk of these funds might be expected to be lower than that of the rest of the funds, or at the least, that the negative effects of non-diversification would be compensated. Nevertheless, according to the classical theory of the firm, social and environmental policies adopted by socially responsible firms raise their operational costs and, as a result, lower financial performance of funds specialising in this type of firm is to be expected.

Following this line of reasoning, the analysis turns to whether the investment policy applied by SRI funds is related to their financial performance so that the following null hypothesis is to be tested:

$\mathrm{H}_{2}$ : The type of screening applied by the fund manager is not related to the performance of the fund.

This hypothesis has previously been analysed for the US fund market by Goldreyer and Diltz (1999), Barnett and Salomon (2006) and Burlacu, Girerd-Potin, and Dupré (2007). In the first two studies, there is evidence of a positive relationship between investment policy and performance of SRI funds (specifically when the fund applies positive screening), whereas in the study by Burlacu et al. (2007), the authors find a negative relationship.

Moreover, SRI funds vary not only in their type of screening (negative and positive) but also in the intensity of their social screening (Barnett, \& Salomon, 2006). Then, this null hypothesis will be tested:

$\mathrm{H}_{3}$ : The intensity of the screening applied by the fund manager is not related to the performance of the fund.

\section{Data selection}

The period of analysis selected for this study has been from January 1993 to December 2012 (a total of 240 monthly periods or 20 years). The whole period was divided into four subperiods of 5 years, each one to investigate the differences in fund performance by time. Nevertheless, many of the analyses realised are concentrated in the past 10 years because a great number of SRI funds were set up after the year 2000.

To carry out the research, first, a list with all equity SRI funds operating in Europe was drawn up using the database that the rating company Vigeo/Avanzi SRI Research maintains 
on European SRI funds. This database supplies information about different characteristics of the European equity SRI funds such as the investment screening policy and includes all funds that apply ethical, social and environmental screens to their investment decisions and which also trade as suppliers of SRIs for the individual investor in general (retail funds). This database, therefore, does not include those funds that simply donate part of their commissions or profits to charity or other good causes (charitable funds), which were considered to be conventional funds. The total number of equity SRI funds in the database was 238 from 14 European countries (Austria, Belgium, Denmark, France, Germany, Ireland, Italy, Luxembourg, Netherlands, Norway, Spain, Sweden, Switzerland and United Kingdom).

To compare the financial performance of SRI funds in the period analysed, all conventional funds with the same domicile and investment objective than SRI funds were taken from the Morningstar Direct's database. This database supplied information on domicile, investment objective, monthly net returns, inception date, size, fees and turnover ratios of each fund. To avoid the survivorship bias, all funds operating during the period of analysis were included in the sample, independent of the number of months in operation. In addition, the most recent issues or categories (A, B, C and so on) of the same fund were omitted from the analysis to avoid duplication in calculations as Statman (2000) and Bello (2005) proposed in their studies.

\section{Methodology}

Monthly net returns were used to calculate funds' performance (risk-adjusted returns), specifically, Carhart's alpha. Carhart's measure estimates a four-factor model that includes the market (MKT), size (SMB), value or book-to-market (HML) and momentum (MOM) factors to control for the impact of investment styles on performance. Thus, the following model has been estimated:

$$
r_{i t}=\alpha_{i}+\beta_{i}^{\mathrm{MKT}} r_{t}^{\mathrm{MKT}}+\beta_{i}^{\mathrm{SMB}} r_{t}^{\mathrm{SMB}}+\beta_{i}^{\mathrm{HML}} r_{t}^{\mathrm{HML}}+\beta_{i}^{\mathrm{MOM}} r_{t}^{\mathrm{MOM}}+\eta_{i t}
$$

where $r_{i t}$ is the excess return of fund $i$ in month $t$ over the monthly return of a risk-free deposit; $r_{t}^{\mathrm{MKT}}$ is the excess return of a market benchmark over the monthly return of a riskfree deposit; $r_{t}^{\mathrm{SMB}}, r_{t}^{\mathrm{HML}}$ and $r_{t}^{\mathrm{MOM}}$ are the SMB, HML and MOM factors, respectively; $\beta_{i}^{\mathrm{MKT}}, \beta_{i}^{\mathrm{SMB}}, \beta_{i}^{\mathrm{HML}}$ and $\beta_{i}^{\mathrm{MOM}}$ are the factor loadings on the four factors and $\eta_{i t}$ stands for the idiosyncratic risk. The term $\alpha_{i}$ is the four-factor alpha and captures funds' risk-adjusted performance according to Carhart's model. Monthly risk-free rate (US 1-month T-bill rate), excess market return (MKT) as well as small minus large (SML), high minus low (HML) and momentum (MOM) factors were collected from the Kenneth French's data library on his website (both Global and European market factors and returns were used in the analysis). All funds' returns are homogenised in US dollars because French's data is presented in this currency.

To investigate the impact of the social factor on the financial performance of SRI funds relative to conventional funds (hypothesis $\mathrm{H}_{1}$ ), this research proposes to estimate the following cross-sectional regression model, which controls the effects of some variables recognised in other former studies such as funds' age, size, management fee and turnover ratio (Burlacu et al., 2007):

$$
\mathrm{PERF}_{i}=\beta_{0}+\beta_{1} \mathrm{AGE}_{i}+\beta_{2} \mathrm{SIZE}_{i}+\beta_{3} \mathrm{FEE}_{i}+\beta_{4} \mathrm{TURN}_{i}+\beta_{5} \mathrm{SOC}_{i}+\varepsilon_{i}
$$


where $\mathrm{PERF}_{i}$ is the 5-year average of performance (measured by Carhart's alpha) for fund $i \mathrm{AGE}_{i}$ is funds' age from its inception date until the last month quoted or December 2012 depending on whatever is first; $\mathrm{SIZE}_{i}$ is the 5-year average funds' total net assets (TNA) in euros; $\mathrm{FEE}_{i}$ is funds' management fee; $\mathrm{TURN}_{i}$ is funds' turnover ratio; $\mathrm{SOC}_{i}$ is a dummy variable that equals 1 for SRI funds and 0 otherwise and $\varepsilon_{i}$ is the residual term.

To evaluate whether the type of screening impacts on funds' performance (hypothesis $\mathrm{H}_{2}$ ), the following model is proposed to estimate:

$$
\mathrm{PERF}_{i}=\beta_{0}+\beta_{1} \mathrm{AGE}_{i}+\beta_{2} \mathrm{SIZE}_{i}+\beta_{3} \mathrm{FEE}_{i}+\beta_{4} \mathrm{TURN}_{i}+\beta_{5} \mathrm{NEG}_{i}+\beta_{6} \mathrm{POS}_{i}+\varepsilon_{i}
$$

where $\mathrm{NEG}_{i}\left(\mathrm{POS}_{i}\right)$ is a dummy variable that equals 1 when the fund $i$ applies negative (positive) screening and 0 otherwise, all other variables being as mentioned earlier.

Finally, a third regression model is proposed to contrast whether the total number of screens that the fund imposes impacts on its financial performance (hypothesis $\mathrm{H}_{3}$ ):

$$
\mathrm{PERF}_{i}=\beta_{0}+\beta_{1} \mathrm{AGE}_{i}+\beta_{2} \mathrm{SIZE}_{i}+\beta_{3} \mathrm{FEE}_{i}+\beta_{4} \mathrm{TURN}_{i}+\beta_{5} \mathrm{INT}_{i}+\beta_{6} \mathrm{INT}_{i}^{2}+\varepsilon_{i}
$$

where $\mathrm{INT}_{i}$ is funds' screening intensity, measured as the number of screens used by fund $i$. This model adds a squared screening intensity term to test whether between the screening intensity and performance variables there is a linear or curvilinear relationship (Barnett, \& Salomon, 2006).

Each of former equations has been estimated using ordinary least squares (OLS) as well as fixed-effects (FE) econometric methods to control for country and investment objective effects.

\section{Empirical results}

\subsection{Descriptive analysis}

Table 1 presents the summary statistics of fund characteristics for each fund category (SRI and conventional) in periods 2003-2007 and 2008-2012. According to the figures in the table, the distribution of the variables AGE, SIZE, FEE and TURN in both groups of funds and for the two periods is very similar. Variables AGE, SIZE and TURN present positive asymmetric distributions whereas FEE, on the contrary, has a slightly skewed distribution to the left. The non-parametric Mann-Whitney test has been used to determine whether mean differences between each type of fund are statistically significant.

Thereby, in the first period, SRI funds are, on average, younger and smaller than conventional funds. Conventional funds are, on average, almost 2 years older and around 150 million of euros larger than SRI funds (marginal differences at the $10 \%$ level). Besides, compared with the rest of funds, social funds have higher management fees and lower turnover ratios being their management fees 16 basis points higher (the average of management fees applied by SRI funds is $1.48 \%$ versus $1.32 \%$ of conventional funds) and their turnover ratios almost 30 times lower (this means that SRI funds manage their portfolios in a more passive way than conventional funds). On the other hand, in period 2008-2012, there is a very significant difference in age being SRI funds 1.35 years older than conventional funds due to new funds created in this period what has decreased the mean age of conventional funds in 3 years. Conventional funds continue being larger than SRI funds but this difference is not statistically significant since the average size of 


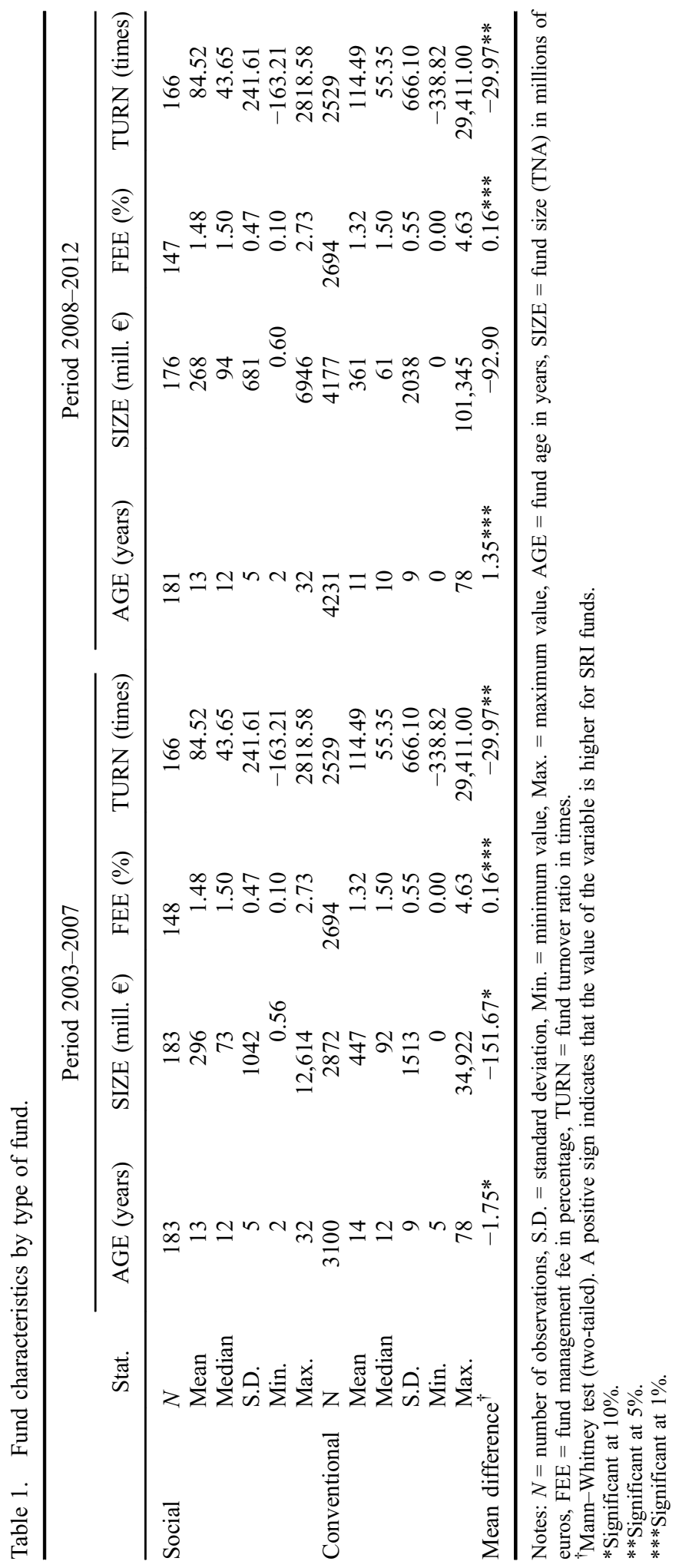


Table 2. Performance means by period (Carhart's alpha).

\begin{tabular}{|c|c|c|c|}
\hline Period & Type of fund & Global benchmark & European benchmark \\
\hline \multirow[t]{3}{*}{ 1993-1997 } & (1) Social $(N=43)$ & 0.3738 & -0.2672 \\
\hline & (2) Conventional $(N=833)$ & 0.1045 & -0.0643 \\
\hline & Difference $^{\dagger}(1)-(2)$ & $0.2693 * *$ & $-0.2029 * *$ \\
\hline \multirow[t]{3}{*}{ 1998-2002 } & (1) Social $(N=143)$ & -0.1422 & 0.2379 \\
\hline & (2) Conventional $(N=2008)$ & -0.0987 & 0.2418 \\
\hline & Difference $^{\dagger}(1)-(2)$ & -0.0435 & -0.0038 \\
\hline \multirow[t]{3}{*}{ 2003-2007 } & (1) Social $(N=183)$ & -0.0505 & -0.2716 \\
\hline & (2) Conventional $(N=3113)$ & -0.0175 & -0.2375 \\
\hline & Difference $^{\dagger}(1)-(2)$ & $-0.0330^{* * *}$ & $-0.0340^{* * *}$ \\
\hline \multirow{3}{*}{ 2008-2012 } & (1) Social $(N=181)$ & -0.2950 & -0.0833 \\
\hline & (2) Conventional $(N=4250)$ & -0.2481 & -0.0566 \\
\hline & Difference $^{\dagger}(1)-(2)$ & $-0.0469 * *$ & $-0.0266^{*}$ \\
\hline \multirow[t]{3}{*}{ 1993-2012 } & (1) Social $(N=184)$ & -0.1453 & -0.1095 \\
\hline & (2) Conventional $(N=4250)$ & -0.1323 & -0.0505 \\
\hline & Difference $^{\dagger}(1)-(2)$ & $-0.0130 * *$ & $-0.0590 * * *$ \\
\hline
\end{tabular}

Notes: $N=$ number of funds. Carhart's alphas are expressed in monthly percentage.

${ }^{\dagger}$ Mann-Whitney test (two-tailed). A positive sign indicates that the value of the variable is higher for SRI funds. * Significant at $10 \%$.

** Significant at $5 \%$.

$* * *$ Significant at $1 \%$.

conventional funds have decreased in almost 93 millions of euros. Finally, management fees and turnover ratios have the same difference than in the former period, with the differences significant at the $1 \%$ and $5 \%$ level, respectively.

The mean values of performance (Carhart's alpha) for each type of fund and period analysed as well as the differences between the mean values of social and conventional funds are presented in Table 2. The number of SRI funds to analyse in the period from 1993 to 2002 is smaller because in Europe the majority of these funds were created after the year 2000. The figures in Table 2 show that, for the whole period 1993-2012 (20 years), SRI funds' monthly measures of performance were, on average, significantly worse than those of conventional funds. For periods 1993-1997 and 1998-2002, the results obtained are not clear because the significant differences in period 1993-1997 have different sign, positive and negative, depending on the market benchmark used to measure the Carhart's alpha or these differences are not statistically significant as it happens in period 1998-2002. Nevertheless, for periods 2003-2007 and 2008-2012, all differences are negative, independently the market benchmark used to compare the funds' performance and, in most cases, very significant what can suggest that the non-existence of statistical significance in previous studies might be motivated by the small number of SRI funds analysed.

Differences in mean performance measures (risk-adjusted returns) segmented by country and investment objective for the last two 5-year subperiods 2003-2007 and 2008-2012 are presented in Table 3. By country, the results with Carhart's alphas show non-significant differences of performance between both types of funds except for funds from France (a difference of -9.08 basis points in the 2003-2007 period with the global benchmark or -6.58 and -5.11 basis points in the 2008-2012 period with both market benchmarks) and the United Kingdom ( -6.40 and -12.21 basis points in the first period or -4.69 and -2.66 basis points in the following period with both market benchmarks). Moreover, SRI funds from Luxembourg and Switzerland also present significant lower performance alphas in the last period 2008-2012 (a difference of -13.42 and -12.29 basis 


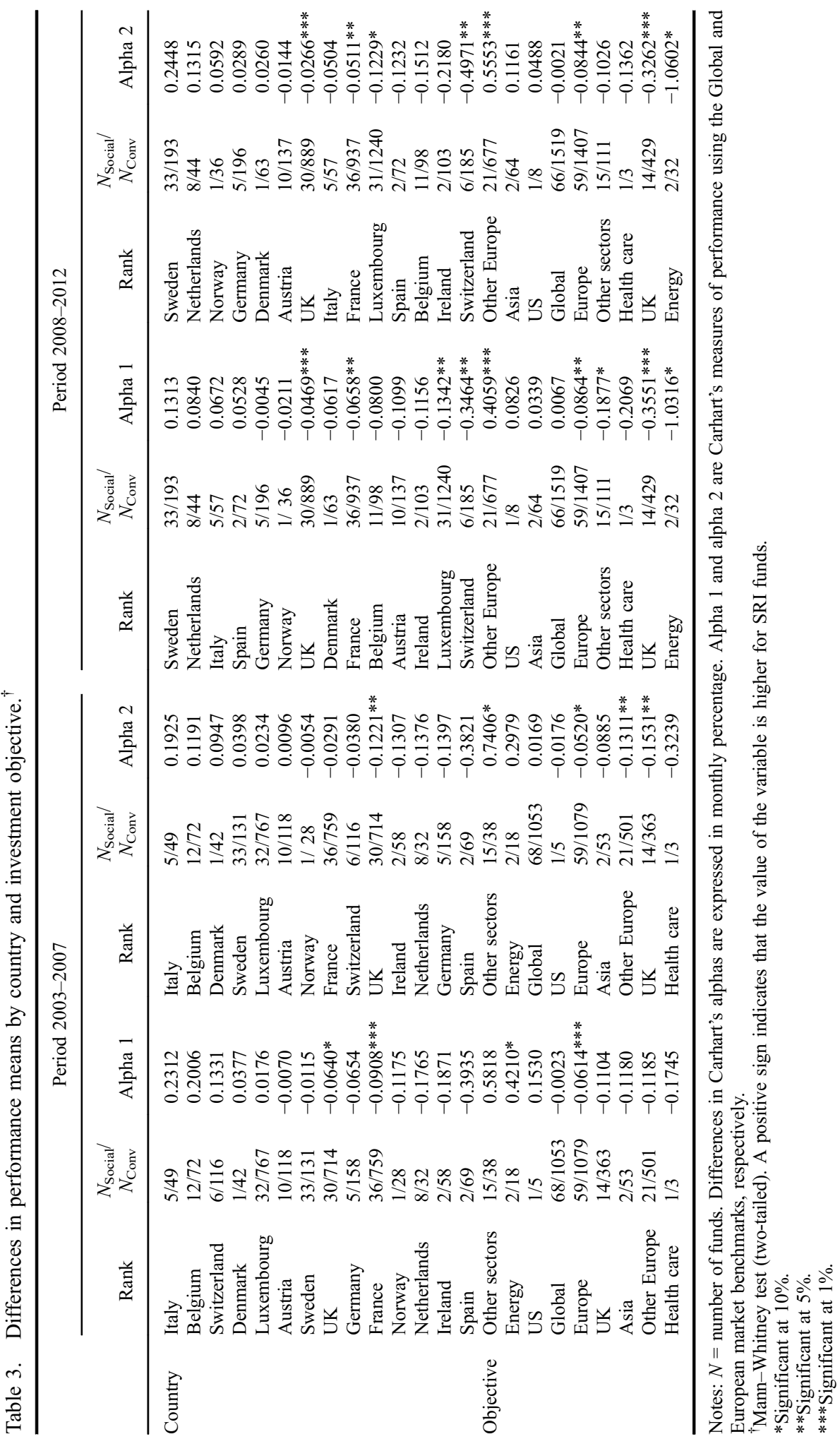


points depending on the benchmark employed in the fist case and a difference of -34.64 and -49.71 basis points in the second case). Similar results are obtained whether performance differences are analysed by the investment objective. Thereby, the majority of performance differences between social and conventional funds are not significant except for those funds investing in European or British portfolios, which have negative and significant differences, independent of the period analysed. Solely, funds investing in energy and other Europe and sectors have a positive and significant difference in favour of SRI funds (in this case, the positive difference is only obtained in one period whereas in the other period the difference is negative).

Although most of these differences, positive or negative, are not statistically significant, the majority of countries present negative differences of performance in favour of conventional funds ( 9 or 8 countries in the first period depending on the market benchmark employed in the analysis and 10 or 9 countries in the following period). Looking at the different rankings of performance in Table 3, it is possible to observe that the sample sizes and the difference magnitudes are both related to get relevant levels of significance because both factors are related to increase or reduce the power of the statistical tests (Cohen, 1988). Thus, when the sample size of social funds is relatively large, a small difference in the alpha value between both types of funds can be statistically significant, whereas when the sample of social funds is smaller, a larger difference in alpha values is necessary to obtain statistical significance between both types of funds. Consequently, a reasonable explanation of the failure to find significant differences in performance between SRI and conventional funds in previous studies may be in the small sample sizes of social funds employed.

The results of this section, therefore, contradict the thesis of the social theory of the firm, in which the application of social criteria in portfolio selection improves the SRI funds' performance, and support the opposing thesis of the classical theory of the firm as well as the modern portfolio theory's argument that restrictions on portfolio selection lead to a lower financial performance.

\subsection{Hypotheses testing: regression results}

Table 4 presents main descriptive statistics and linear correlations among the variables used in the regressions to test the hypotheses of this research for periods 2003-2007 and 2008-2012. The figures given in the table show a significant correlation among certain variables (significance at the $10 \%$ level or less). Thus, financial performance is positively correlated with size $(r=0.045$ or 0.062 in the first period depending on the performance measure used 1 or 2 and $r=0.062$ in the second period and when the global market benchmark is used), what is explained by scale effects, and negatively with management fees $(r=-0.049$ in the 2003-2007 period and $r=-0.237$ or -0.188 in the following period depending on the benchmark employed to calculate the Carhart's alpha) and turnover ratios $(r=-0.064$ or -0.054 in the second period depending on the measure of performance) so that funds with higher management fees and more active strategies in portfolio management present lower risk-adjusted returns. Moreover, size and management fees are positively correlated with funds' age ( $r=0.177$ and 0.032 , respectively, in the first period and 0.080 and 0.032 in the second period) so that funds with more years operating in the market correspond to those with higher fees and larger assets.

The application of social screening on investment decisions, independently as it is measured (by type of fund, type of screening or screening intensity), is positively correlated with funds' management fees (what means that SRI funds have, on average, 


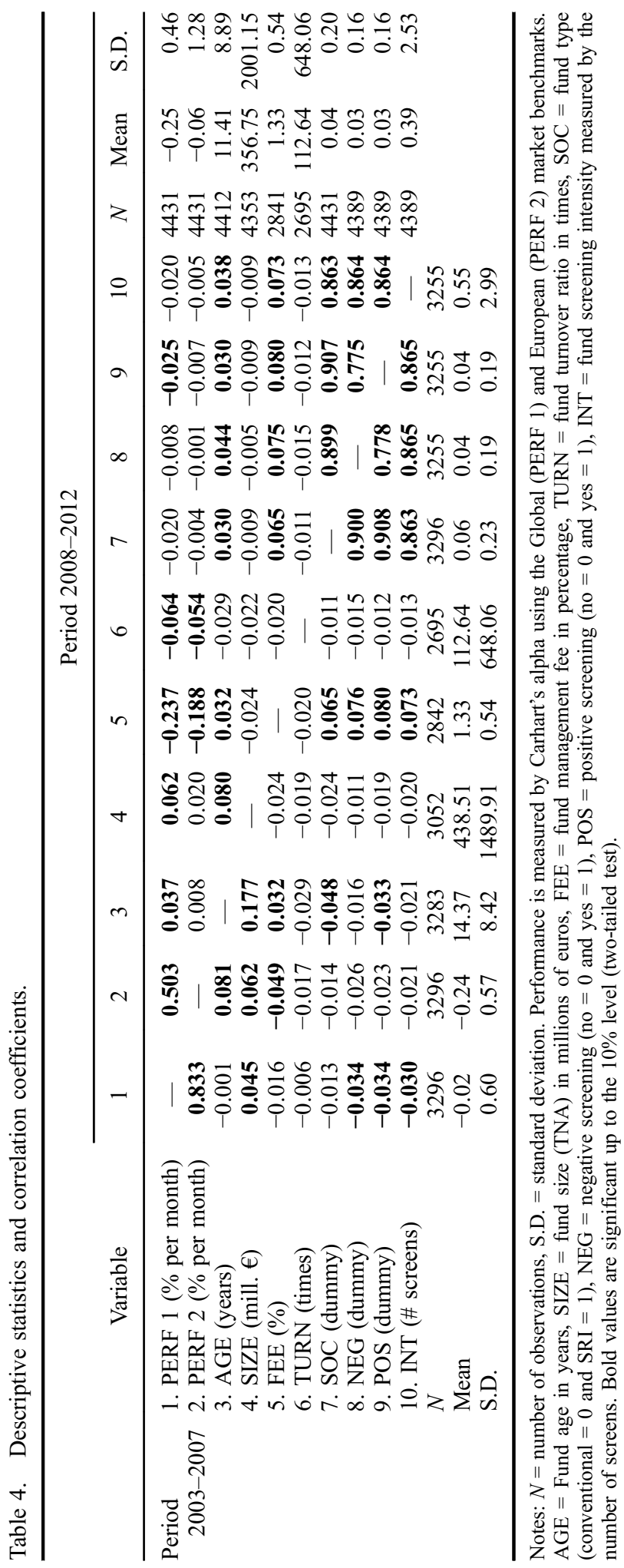


higher management fees than the rest of the funds) and negatively with funds' financial performance (measured by Carhart's alpha). This relationship between the application of social screening and financial performance is stronger and more significant when the global market benchmark is used and when the first period is analysed. In the case of funds with positive screening, these are a little younger than the rest of funds $(r=-0.033$ or -0.030 depending on the period analysed). Furthermore, figures in Table 4 also suggest that most funds using negative screens apply, at the same time, positive screening independent of the period analysed ( $r=0.778$ and 0.775 , respectively).

As for the screening strategy of SRI funds (see Table 5), the screening intensity average of the 142 social funds with screening information in the sample is of 12.6 screens applying, on average, 6.9 negative and 5.7 positive screens. The distribution of screening intensity among SRI funds is that half of these funds has a low screening intensity (between 1 and 10 screens), 33.8\% have a medium screening intensity (between 11 and 20 screens) and the rest of funds, 23 out of 142 (a 16.2\%), have a high screening intensity (21 or more screens). By country, Switzerland, United Kingdom and Norway are the countries where SRI funds have, on average, more screening intensity $(22.3,19.4$ and 19.0 screens, respectively), whereas France, Sweden and Spain are the countries where social funds have the lowest screening intensity $(6.5,6.9$ and 7.5 screens, respectively). Although in the majority of countries social funds apply both negative and positive screens, the case of France and Sweden is relevant because funds of these countries apply a strategy of low screening based mainly on negative screens in the case of

Table 5. Screening strategy of SRI funds by country and investment objective. ${ }^{\dagger}$

\begin{tabular}{|c|c|c|c|c|c|c|c|c|c|}
\hline & & \multicolumn{2}{|c|}{ Negative screening } & \multicolumn{2}{|c|}{ Positive screening } & \multicolumn{4}{|c|}{ Screening intensity } \\
\hline & & $\begin{array}{l}\text { \# screens } \\
\text { (mean) }\end{array}$ & $\begin{array}{l}\text { \# funds } \\
\text { (sum) }\end{array}$ & $\begin{array}{l}\text { \# screens } \\
\text { (mean) }\end{array}$ & $\begin{array}{l}\text { \# funds } \\
\text { (sum) }\end{array}$ & $\begin{array}{l}\text { \# screens } \\
\text { (mean) }\end{array}$ & $\begin{array}{c}\text { Low } \\
\text { (\# funds) }\end{array}$ & $\begin{array}{l}\text { Medium } \\
\text { (\# funds) }\end{array}$ & $\begin{array}{c}\text { High } \\
\text { (\# funds) }\end{array}$ \\
\hline \multirow[t]{14}{*}{ Country } & Austria & 5.5 & 7 & 6.3 & 8 & 11.8 & 6 & 3 & 1 \\
\hline & Belgium & 5.0 & 5 & 9.1 & 7 & 14.1 & 2 & 4 & 1 \\
\hline & Denmark & 5.0 & 1 & 10.0 & 1 & 15.0 & 0 & 1 & 0 \\
\hline & France & 1.3 & 8 & 5.3 & 22 & 6.5 & 20 & 3 & 0 \\
\hline & Germany & 7.8 & 4 & 6.3 & 4 & 14.0 & 1 & 3 & 0 \\
\hline & Ireland & 11.5 & 2 & 7.0 & 2 & 18.5 & 0 & 1 & 1 \\
\hline & Italy & 7.8 & 5 & 6.0 & 5 & 13.8 & 0 & 5 & 0 \\
\hline & Luxembourg & 7.0 & 21 & 7.4 & 22 & 14.4 & 10 & 11 & 4 \\
\hline & Netherlands & 8.8 & 6 & 7.0 & 6 & 15.8 & 3 & 1 & 2 \\
\hline & Norway & 9.0 & 1 & 10.0 & 1 & 19.0 & 0 & 1 & 0 \\
\hline & Spain & 4.0 & 2 & 3.5 & 2 & 7.5 & 2 & 0 & 0 \\
\hline & Sweden & 5.1 & 25 & 1.9 & 12 & 6.9 & 25 & 2 & 0 \\
\hline & Switzerland & 12.3 & 4 & 10.0 & 4 & 22.3 & 0 & 1 & 3 \\
\hline & $\begin{array}{l}\text { United } \\
\text { Kingdom }\end{array}$ & 13.4 & 25 & 5.9 & 22 & 19.4 & 2 & 12 & 11 \\
\hline \multirow[t]{9}{*}{ Objective } & Asia & 3.0 & 1 & 10.0 & 1 & 13.0 & 0 & 1 & 0 \\
\hline & Europe & 3.5 & 21 & 6.0 & 34 & 9.4 & 26 & 12 & 0 \\
\hline & Global & 8.2 & 54 & 6.4 & 49 & 14.6 & 21 & 25 & 13 \\
\hline & Energy & 5.0 & 1 & 2.0 & 1 & 7.0 & 1 & 0 & 0 \\
\hline & Health care & 5.0 & 1 & 2.0 & 1 & 7.0 & 1 & 0 & 0 \\
\hline & Other Europe & 5.5 & 15 & 2.9 & 11 & 8.4 & 15 & 1 & 1 \\
\hline & Other sectors & 7.0 & 8 & 6.2 & 10 & 13.2 & 5 & 3 & 2 \\
\hline & UK & 13.2 & 14 & 5.7 & 11 & 18.9 & 1 & 6 & 7 \\
\hline & US & 5.0 & 1 & 0.0 & 0 & 5.0 & 1 & 0 & 0 \\
\hline \multicolumn{2}{|c|}{ All countries/objectives } & 6.9 & 116 & 5.7 & 118 & 12.6 & 71 & 48 & 23 \\
\hline
\end{tabular}

Note: ${ }^{\dagger}$ Data at December 2007 supplied by Vigeo/Avanzi SRI Research. 
Sweden (25 funds with negative screens versus 12 funds with positive screens) or positive screens in the case of France ( 22 funds with positive screens versus 8 funds with negative screens). Taking into account the investment objective, European SRI equity funds investing in British companies are the funds with the highest screening intensity (18.9 screens), whereas SRI funds investing in US companies or in the energy and health care sectors have the lower screening intensity (5 and 7 screens, respectively). As it was mentioned earlier, the majority of the European equity SRI funds apply both types of screening (negative and positive) although SRI funds investing mainly in European companies prefer to apply a positive screening strategy (34 funds with positive screens versus 21 funds with negative screens).

The results of the regression analysis for period 2003-2007 are presented in Tables 6 and 7 depending on the market benchmark employed to measure Carhart's alphas (the Global or European market, respectively), whereas the results for period 2008-2012 are presented in Tables 8 and 9. For period 2003-2007, regression results vary depending on the market benchmark used in the analysis. With the Global market benchmark (see Table 6), the results show that funds' age is negatively related to financial performance, whereas with the European benchmark (see Table 7), both variables are related positively. Funds' management fees and turnover ratios are related to risk-adjusted returns negatively although only the first variable is statistically significant and for the second market benchmark. On the other hand, funds' size is positively related to financial performance in any case. The results for period 2008-2012 are very similar, independent of the market benchmark employed. Thus, in both cases (see Tables 8 and 9), funds' size is positively related to financial performance, whereas funds' management fees and turnover ratios are related to it negatively, which is in accordance with financial theory. The effects of size and management fees on financial performance are very significant in any case (at the $1 \%$ and $5 \%$ level), whereas the effect of turnover ratios is only significant when the FE of country and investment objective are controlled. In the case of funds' age the relationship is only significant when its effect is positive and FE are not controlled.

As for the effect of the application in investment decisions of ethical, social and environmental criteria (social screening) on funds' financial performance, this study has found a negative relationship between both variables. When the effect of the type of fund (social or conventional) is analysed, the relationship between both variables is not statistically significant for period 2003-2007 but significant for period 2008-2012 (except when the FE of the investment objective are controlled). Therefore, according to the empirical evidence, hypothesis $\mathrm{H}_{1}$ has to be rejected at least for the most recent period 2008-2012.

Whether the type of screening is taken into account, SRI funds applying negative and positive screens show a negative difference in performance although this difference is not statistically significant in many cases. Nevertheless, significant differences change from one variable to other (negative or positive screening) depending on the market benchmark applied, the period analysed or the model estimated. Consequently, there is no clear result as to how is the relationship between the type of screening and funds' performance whereby hypothesis $\mathrm{H}_{2}$ cannot be rejected. The application of both types of screening at the same time by the majority of European SRI funds could be the reason for this inconclusive result.

When the screening intensity is analysed, it has been found that there is a negative coefficient for screening intensity (measured by the number of social screens applied by the fund manager) as well as a positive coefficient for its quadratic although these results are only significant for the period 2003-2007 and for the Global benchmark. Hypothesis 


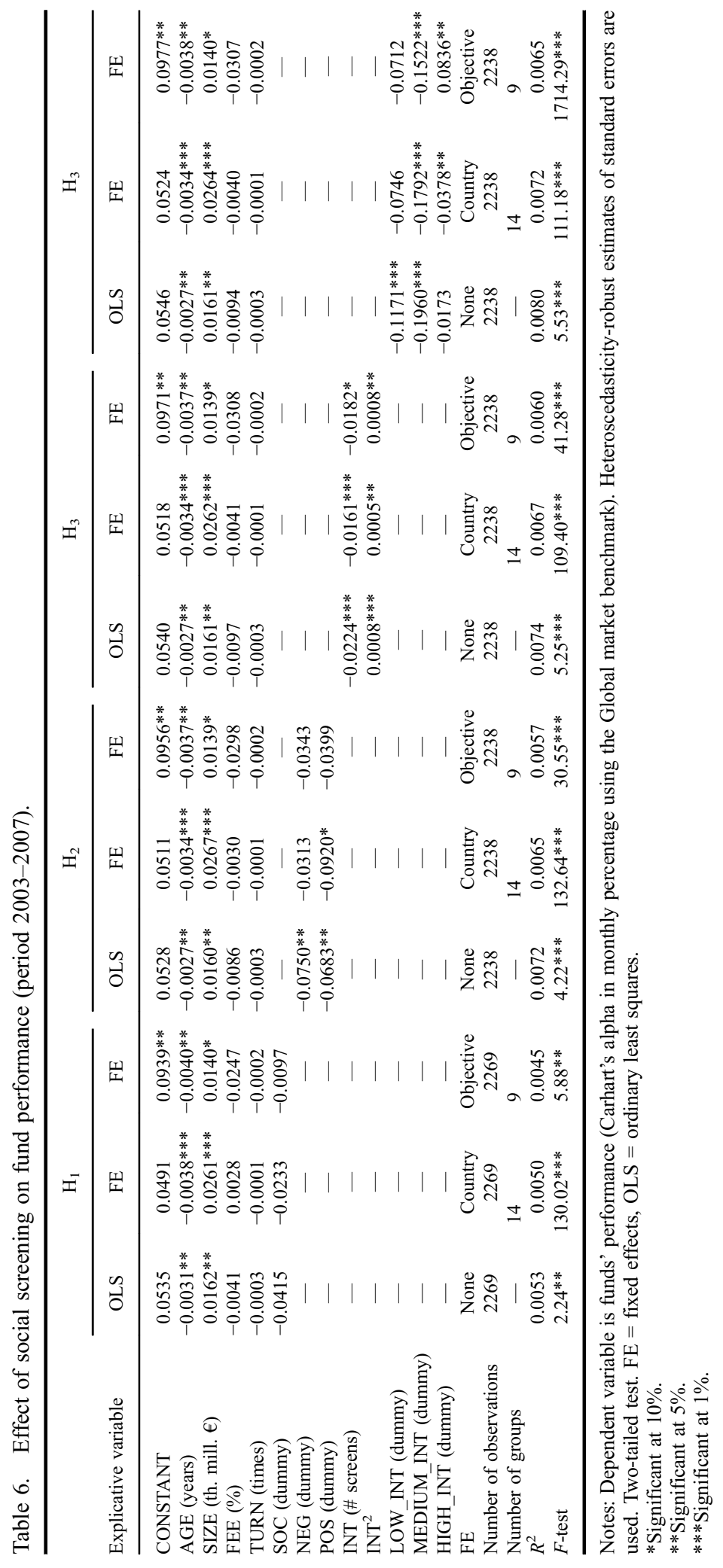




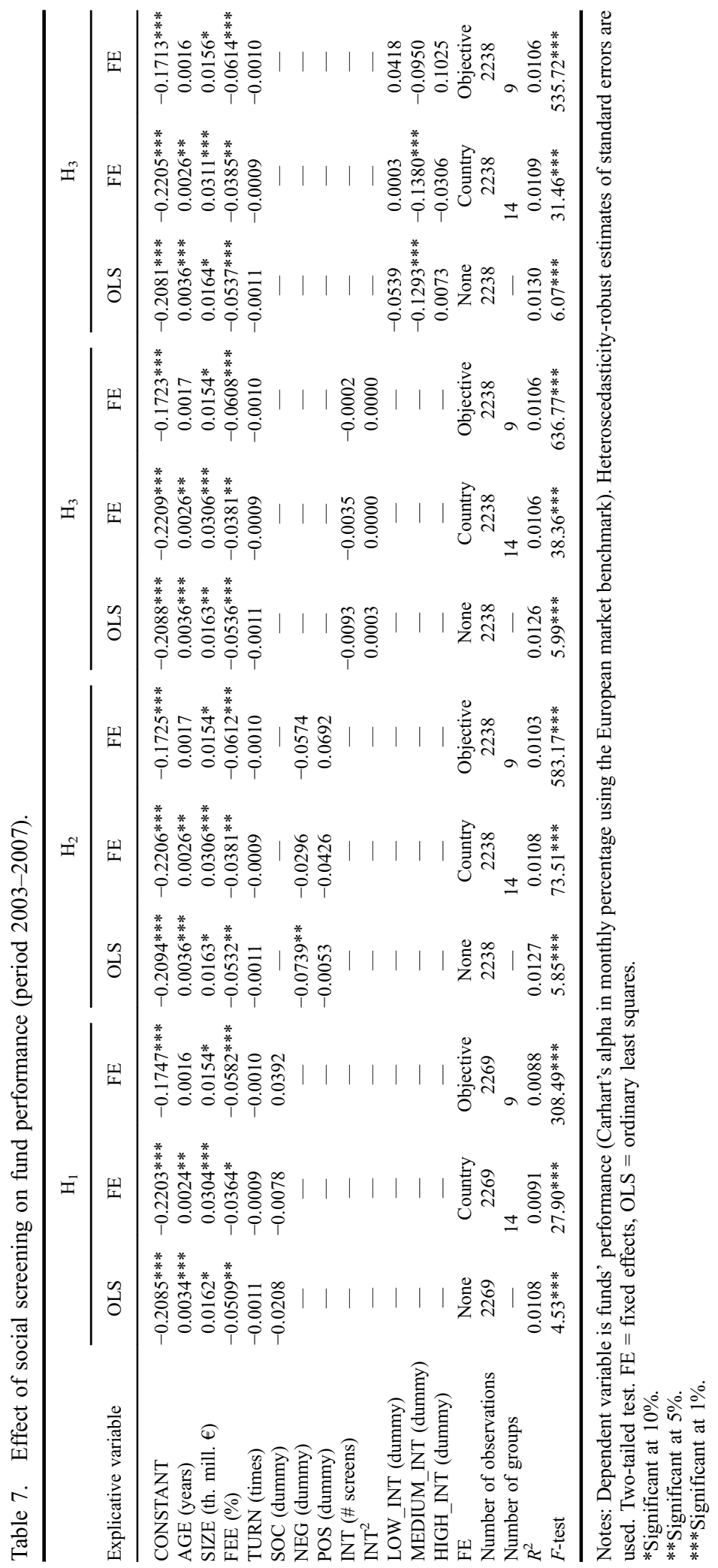




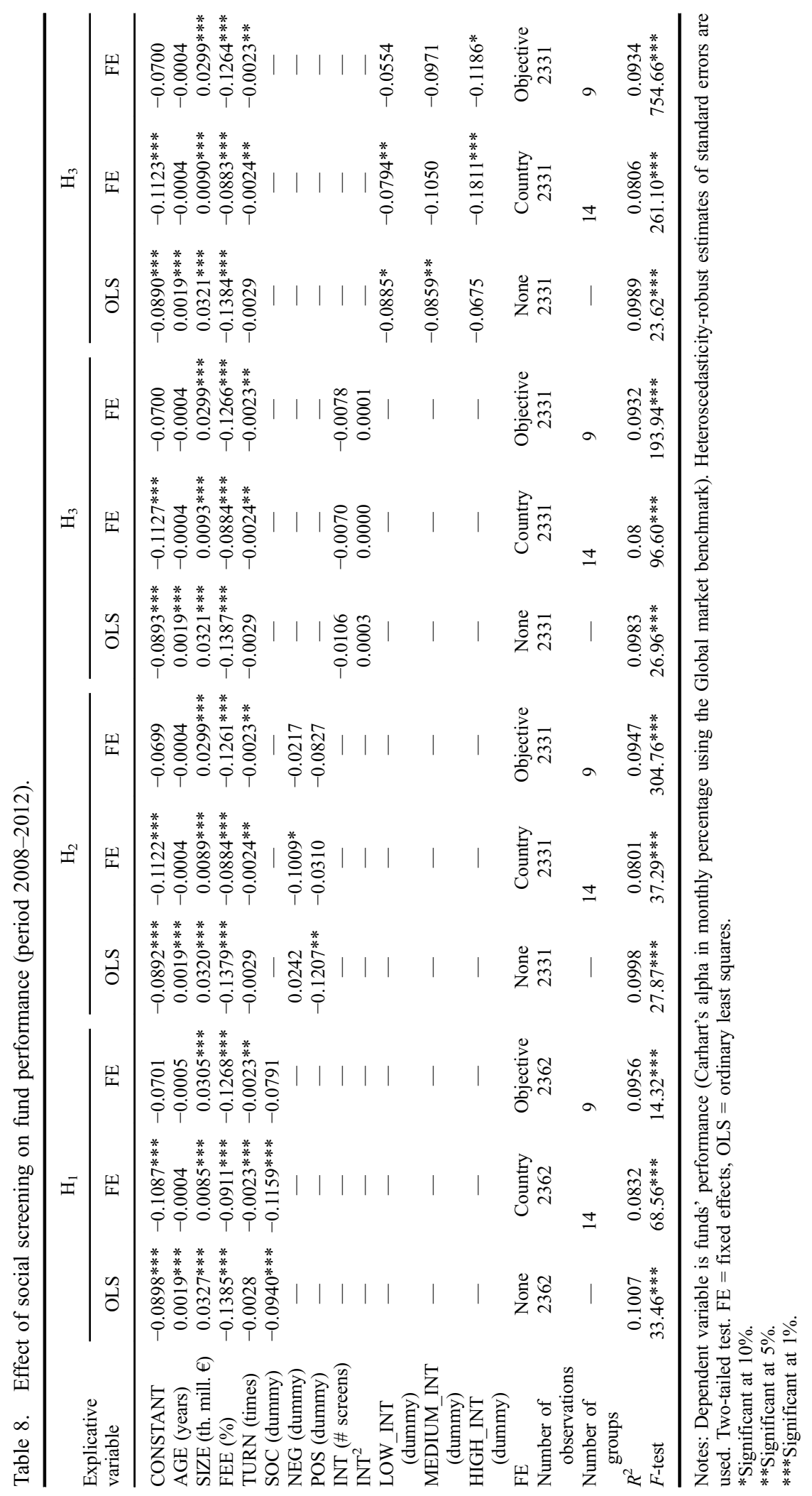




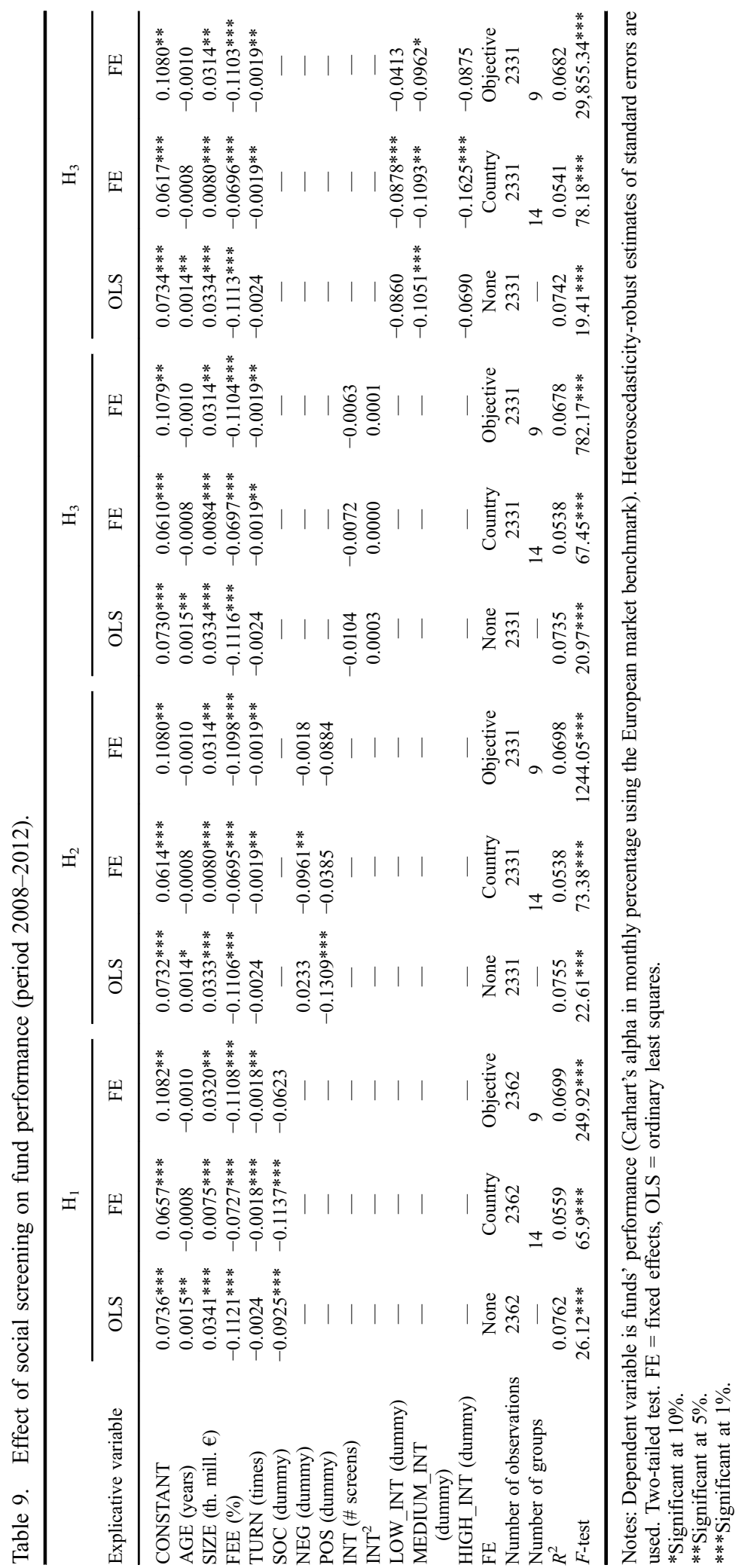


$\mathrm{H}_{3}$ has also been analysed by changing the variable to account for the screening intensity and by introducing into the models three dummy variables: LOW_INT when the SRI fund is between 1 and 10 screens, MEDIUM_INT when it is between 11 and 20 screens and HIGH_INT when it is 21 or more screens. The results with these new variables reveal that, for period 2003-2007, when SRI fund managers apply a medium screening intensity (between 11 and 20 screens), the financial performance of these funds is worse than that of conventional funds, whereas when they apply low or high screening intensity on their portfolios, SRI funds have the same financial performance than conventional funds. This result implies a curvilinear relationship between screening intensity and fund performance as Barnett and Salomon (2006) found in their research of the US SRI funds. Thus, riskadjusted return declines at first as screening intensity increases, reaching a minimum, but then increases continuously until it reaches the maximum social screening intensity of 34 screens. Nonetheless, this relationship is linear and inverse for period 2008-2012 so that the more screening intensity, the lower performance of the fund, this result being obtained both for market benchmarks and controlling for country and objective FE. According to this result, hypothesis $\mathrm{H}_{3}$ has to be rejected.

\section{Conclusions}

This section summarises the main results of the empirical analysis about the differences in financial performance between SRI and conventional equity funds using a large sample of European social funds (184 funds) from 14 different countries. The period of time used to analyse the monthly performance measures (Carhart's alphas) of these funds was 20 years from January 1993 to December 2012.

According to the results obtained in the descriptive analysis, differences in performance (once the four risk factors market, size, style and momentum are controlled) between SRI and conventional funds were negative and significant for the whole period 1993-2012. This result is also present in subperiods 2003-2007 and 2008-2012 although, when the analysis is segmented by countries, many of them present no significant differences in performance. Nevertheless, SRI funds from some countries such as France and the United Kingdom performed significantly worse than conventional funds in both subperiods 2003-2007 and 2008-2012. The short number of social funds in the sample for each country could be the reason for this result since there is a relationship among sample sizes, levels of significance and the magnitude of the difference. Thus, a reasonable explanation of the failure to find significant differences in performance between SRI and conventional funds in previous studies may be in the small sample sizes of social funds used for each country.

The results obtained in the regression analysis show that the differences in performance between SRI and conventional funds can be explained by differences in funds' size and management fees charged by fund managers. This fact has also been found in other empirical studies referring to other periods and geographical areas (Bauer et al., 2003; Bauer et al., 2005; Burlacu et al., 2007; Geczy, Stambaugh, \& Levin, 2003).

Another interesting result of this research is that the type of screening used by the fund is not relevant to explain differences in funds' performance since both types of screening (negative and positive) are used at the same time for the majority of European equity SRI funds. Nevertheless, despite the negative effect of size and fees on SRI funds' financial performance, a worse performance of these funds can be also explained by the screening intensity applied by social fund managers. Thus, it can be concluded that the application of more screens on investment decisions really reduce funds' performance although the 
functional relationship between both variables is not always the same (linear or curvilinear) depending on the period analysed.

Since investment restrictions are behind the underperformance of social funds, this result provides evidence supporting the premises of the modern portfolio theory, while no evidence has been found to support the thesis of the classical and social theories of the firm that the type of equity in which social funds are investing (sustainable companies) is affecting, positively or negatively, the funds' financial performance. Therefore, social screening has a cost for SRI funds' investors.

\section{References}

Barnett, M. L., \& Salomon, R. M. (2006). Beyond dichotomy: The curvilinear relationship between social responsibility and financial performance. Strategic Management Journal, 27(11), 11011122. doi: $10.1002 / \mathrm{smj} .557$

Bauer, R., Derwall, J., \& Otten, R. (2003). Canadian ethical mutual funds performance and investment style analysis in a multifactor framework (Working paper 03-001). Maastricht University, Maastricht, the Netherlands.

Bauer, R., Koedijk, K., \& Otten, R. (2005). International evidence on ethical mutual fund performance and investment style. Journal of Banking and Finance, 29(7), 1751-1767. doi:10.1016/j. jbankfin.2004.06.035

Belkaoui, A., \& Karpik, P. G. (1989). Determinants of the corporate decision to disclose social information. Accounting, Auditing and Accountability Journal, 2(1), 36-51. doi:10.1108/ 09513578910132240

Bello, Z. Y. (2005). Socially responsible investing and portfolio diversification. Journal of Financial Research, 28(1), 41-57. doi:10.1111/j.1475-6803.2005.00113.x

Boasson, V., Cheng, J., \& Boasson, E. (2004). Are investment managers investing ethically at a disadvantage. Journal of Applied Management and Entrepreneurship, 9(4), 56-65.

Burlacu, R., Girerd-Potin, I., \& Dupré, D. (2007). What is behind the financial performance of ethical funds? A study of the American market. In Gregoriou, G. N. (Ed.), Performance of mutual funds an international perspective (Chapter 10, pp. 183-209). New York: PalgraveMacMillan.

Cohen, J. (1988). Statistical power analysis for the behavioral sciences (2nd ed.). Hillsdale, NJ: Lawrence Erlbaum Associates.

Fernández Sánchez, J. L., \& Luna Sotorrío, L. (2006). Análisis comparativo de eficiencia de los fondos de inversión sociales españoles frente a los fondos de inversión tradicionales en el período 2000-2004. Spanish Journal of Finance and Accounting / Revista Española De Financiación Y Contabilidad, 35(128), 181-197. doi:10.1080/02102412.2006.10779578

Fernandez-Izquierdo, A., \& Matallin-Saez, J. C. (2008). Performance of ethical mutual funds in Spain: Sacrifice or premium?. Journal of Business Ethics, 81(2), 247-260. doi:10.1007/s10551007-9492-3

Geczy, C. C., Stambaugh, R. F., \& Levin, D. (2003). Investing in socially responsible mutual funds. Philadelphia, PA: Wharton School, University of Pennsylvania.

Goldreyer, E. F., \& Diltz, J. D. (1999). The performance of socially responsible mutual funds: Incorporating sociopolitical information in portfolio selection. Managerial Finance, 25(1), 23 36. doi:10.1108/03074359910765830

Gregory, A., Matatko, J., \& Luther, R. (1997). Ethical unit trust financial performance: Small company effects and fund size effects. Journal of Business Finance and Accounting, 24(5), 705-725. doi:10.1111/1468-5957.00130

Gregory, A., \& Whittaker, J. (2007). Performance and performance persistence of 'ethical' unit trusts in the UK. Journal of Business Finance and Accounting, 34(7-8), 1327-1344. doi:10.1111/ j.1468-5957.2007.02006.x

Guerard Jr, J. B. (1997). Is there a cost to being socially responsible in investing? The Journal of Investing, 6(2), 11-18. doi:10.3905/joi.1997.408416

Hamilton, S., Jo, H., \& Statman, M. (1993). Doing well while doing good? The investment performance of socially responsible mutual funds. Financial Analysts Journal, 49(6), 62-66. doi:10.2469/faj.v49.n6.62 
Hickman, K. A., Teets, W. R., \& Kohls, J. J. (1999). Social investing and modern portfolio theory. American Business Review, 17(1), 72-78.

Kreander, N., Gray, R. H., Power, D. M., \& Sinclair, C. D. (2005). Evaluating the performance of ethical and non-ethical funds: A matched pair analysis. Journal of Business Finance and Accounting, 32(7-8), 1465-1493. doi:10.1111/j.0306-686X.2005.00636.x

Kurtz, L. (1997). No effect, or no net effect? studies on socially responsible investing. The Journal of Investing, 6(4), 37-49. doi:10.3905/joi.1997.37

Luther, R. G., Matatko, J., \& Corner, D. C. (1992). The investment performance of UK “ethical” unit trusts. Accounting, Auditing and Accountability Journal, 5(4), 57-70. doi:10.1108/ 09513579210019521

Mallin, C. A., Saadouni, B., \& Briston, R. J. (1995). The financial performance of ethical investment funds. Journal of Business Finance and Accounting, 22(4), 483-496. doi:10.1111/j.14685957.1995.tb00373.x

Matallín Sáez, J. C., \& Fernández Izquierdo, M. A. (2002). Estudio de la gestión de fondos de inversión en el ámbito de las entidades financieras de carácter cooperativo. Valencia: Fundación Ruralcaja.

Rudd, A. (1981). Social responsibility and portfolio performance. California Management Review, 23(4), 55-61. doi:10.2307/41164931

Scholtens, B. (2005). Style and performance of Dutch socially responsible investment funds. The Journal of Investing, 14(1), 63-72. doi:10.3905/joi.2005.479390

Statman, M. (2000). Socially responsible mutual funds. Financial Analysts Journal, 56(3), 30-39. doi:10.2469/faj.v56.n3.2358

Tippet, J. (2001). Performance of Australia's ethical funds. The Australian Economic Review, 34(2), 170-178. doi:10.1111/1467-8462.00186 
Reproduced with permission of the copyright owner. Further reproduction prohibited without permission. 